\title{
Phylogenetic Relationship of Phosphate Solubilizing Bacteria according to $16 S$ rRNA Genes
}

\author{
Mohammad Bagher Javadi Nobandegani, Halimi Mohd Saud, and Wong Mui Yun \\ Institute Tropical Agriculture, Universiti Putra Malaysia, 43400 Serdang, Selangor, Malaysia \\ Correspondence should be addressed to Mohammad Bagher Javadi Nobandegani; mbjavadi2002@yahoo.com
}

Received 30 June 2014; Revised 2 September 2014; Accepted 10 September 2014

Academic Editor: Qaisar Mahmood

Copyright ( 2015 Mohammad Bagher Javadi Nobandegani et al. This is an open access article distributed under the Creative Commons Attribution License, which permits unrestricted use, distribution, and reproduction in any medium, provided the original work is properly cited.

\begin{abstract}
Phosphate solubilizing bacteria (PSB) can convert insoluble form of phosphorous to an available form. Applications of PSB as inoculants increase the phosphorus uptake by plant in the field. In this study, isolation and precise identification of PSB were carried out in Malaysian (Serdang) oil palm field (University Putra Malaysia). Identification and phylogenetic analysis of 8 better isolates were carried out by $16 \mathrm{~S}$ rRNA gene sequencing in which as a result five isolates belong to the Beta subdivision of Proteobacteria, one isolate was related to the Gama subdivision of Proteobacteria, and two isolates were related to the Firmicutes. Bacterial isolates of 6 upmr, 2upmr, 19 upmnr, $10 \mathrm{upmr}$, and $24 \mathrm{upmr}$ were identified as Alcaligenes faecalis. Also, bacterial isolates of $20 \mathrm{upmnr}$ and 17upmnr were identified as Bacillus cereus and Vagococcus carniphilus, respectively, and bacterial isolates of 31upmr were identified as Serratia plymuthica. Molecular identification and characterization of oil palm strains as the specific phosphate solubilizer can reduce the time and cost of producing effective inoculate (biofertilizer) in an oil palm field.
\end{abstract}

\section{Introduction}

Phosphorus is the least available essential nutrients where its concentrations are less than many other nutrients in soil. Since available phosphorus seldom exceeds $10 \mu \mathrm{M}$ in soil, the lack of that is common in most soil $[1,2]$. Available inorganic $\mathrm{P}$ in soil solution is $2 \mu \mathrm{M}$ and it is several orders of size lower than that in plant tissues $(5-20 \mathrm{mM})$. In the other hand, aluminum, iron, and calcium interact strongly with $\mathrm{P}$ and make it unavailable to plants. Also, twenty to eighty percent of phosphate in soil is in organic form [3]; it should be mineralized into inorganic form before it becomes available for plant up-taking. Several bacterial and fungal species were reported as phosphate solubilizer in crops and some of them were used as biofertilizers in agricultural fields [1].

With the aid of molecular technologies, the study of microbial ecology and understanding the place of microorganisms in society were made easy [4-7]. These days, interest for molecular identification of bacteria based on the better understanding of their biological role in keeping a sustainable biosphere has been increased [8-11]. Sequence analysis of
$16 \mathrm{~S}$ rRNA gene can find phylogenetic relationships between bacteria [11-15].

Studies have shown that diversity of microorganism in soil is large [16]. Therefore, the aim for identifying communities of microorganisms with key roles in specific soil chemical processes such as phosphate solubilization is important in soil microbiology [17-21]. The objective of this study was to isolate, identify, and characterize phosphate solubilizing bacteria from rhizosphere and nonrhizosphere of oil palm in University Putra Malaysia’s soil (Serdang).

\section{Materials and Methods}

2.1. Soil Sampling. Soil samples were collected from oil palm plantation at University Putra Malaysia, Serdang $\left(+2^{\circ}\right.$ $\left.59^{\prime} 9.666^{\prime \prime}:+101^{\circ} 43^{\prime} 23.5416^{\prime \prime}\right)$. The samples were taken randomly from mature oil palm plantations (eight years) at a depth of $15-20 \mathrm{~cm}$. Sampling was done in a manner which ensure that no cross contamination can occur between rhizosphere and nonrhizosphere samples. Soil samples were 
TABle 1: Soil analysis.

\begin{tabular}{|c|c|c|c|c|c|c|c|c|c|c|c|}
\hline \multirow{2}{*}{ Sample } & \multicolumn{4}{|c|}{$\%$} & \multicolumn{6}{|c|}{$\mu \mathrm{g} / \mathrm{g}$} & \multirow[b]{2}{*}{$\mathrm{Zn}$} \\
\hline & $\mathrm{pH}$ & $\mathrm{C}$ & $\mathrm{N}$ & $\mathrm{P}$ & $\mathrm{K}$ & $\mathrm{Ca}$ & $\mathrm{Mg}$ & $\mathrm{Cu}$ & $\mathrm{Fe}$ & $\mathrm{Mn}$ & \\
\hline UPMNR & $5.4^{\mathrm{a}}$ & $1.6^{\mathrm{b}}$ & $0.1^{\mathrm{b}}$ & $39.8^{\mathrm{b}}$ & $38^{\mathrm{b}}$ & $402^{\mathrm{a}}$ & $81^{b}$ & $0.89^{\mathrm{a}}$ & $0.89^{\mathrm{a}}$ & $3^{\mathrm{b}}$ & $2^{\mathrm{b}}$ \\
\hline UPMR & $5.0^{\mathrm{b}}$ & $5.8^{\mathrm{a}}$ & $0.43^{\mathrm{a}}$ & $45.3^{\mathrm{a}}$ & $129^{\mathrm{a}}$ & $337^{\mathrm{b}}$ & $102^{\mathrm{a}}$ & $0.52^{\mathrm{b}}$ & $0.52^{\mathrm{a}}$ & $10^{\mathrm{a}}$ & $6^{\mathrm{a}}$ \\
\hline
\end{tabular}

In each column followed by different letters are significantly different $(P<0.05)$ according to ANOVA test performed with SPSS 10.1 Software. UPMNR: UPM nonrhizosphere and UPMR: UPM rhizosphere.

then analyzed to determine the chemical elements including Nitrogen [22], Phosphorus (P) [23], Potassium (K), Calcium (Ca) Magnesium (Mg) [24], Zinc (Zn), Iron (Fe), Manganese (Mn), and Copper (Cu) [25] (Table 1).

\subsection{Isolation of Phosphate Solubilizing Bacteria. Bacterial} isolates were isolated from soil samples by using root-free soil as nonrhizosphere and also by using soil which is surrounding the root of oil palm as Rhizosphere. Ten grams of soil was diluted in $95 \mathrm{~mL}$ of sterile water to form a serial dilution up to $10^{-6}$. Then, $0.1 \mathrm{~mL}$ of the final three dilutions was individually plated on Pikovskaya (PVK) media [26]. Bacteria which represent clearing halozone on the plates were selected and purified on PVK media [27]. The eight bacterial isolates were selected for further study based on the high performance of phosphate solubilization [28].

\subsection{Identification of Phosphate Solubilizing Bacteria Using} $16 S$ rRNA Gene. All eight isolates were grown in Luria Broth Agar (LBA) media. Bacteria were grown at $28^{\circ} \mathrm{C}$ for 18 hours in a shaking incubator (Amersham Pharmacia Biotech) (200 rpm) [29]. Genomic DNA was extracted from bacterial isolates using a commercial kit (Qiagen Miniprep 27104 Matrix Technologies Cooperation, USA) according to the manufacturer's instructions. Then, DNA was stored at $-20^{\circ} \mathrm{C}$. The concentration and purity of the extracted DNA were determined spectrophotometrically [29]. Two universal oligonucleotide forward and reverse primers were synthesized based on the standard 16S rRNA gene sequence [30]. The primers used to amplify the $16 \mathrm{~S}$ rDNA samples were forward primer: $-5^{\prime}$-CCGAATTCGTCGACAACAGAGTTTGATCCTGGCTCAG-3' and reverse primer: - $5^{\prime}$ CCCGGATCCAAGCTTACGGCTACCTTGTTACGACTT$3^{\prime}$.

2.4. PCR Amplification. PCR amplification was performed in a total volume of $50 \mu \mathrm{L}$ mixture. It contained $5 \mu \mathrm{L}$ of $10 \mathrm{x}$ PCR buffer, $0.5 \mu \mathrm{L}$ of $10 \mathrm{x} d N T P, 1 \mu \mathrm{L}$ of forward and $1 \mu \mathrm{L}$ of reverse primer, $1.3 \mu \mathrm{L}$ of template DNA (10 ng), $1 \mu \mathrm{L}$ of Taq DNA polymerase, and sterile distilled water adjusted to $50 \mu \mathrm{L}$. The tubes were subjected to 35 cycles in a thermal cycler with the following program: initial denaturation at $95^{\circ} \mathrm{C}$ for 3 minutes which was followed with 35-cycle consisting of denaturation at $94^{\circ} \mathrm{C}$ for 30 seconds, annealing at $60^{\circ} \mathrm{C}$ for 30 seconds, and elongation at $72^{\circ} \mathrm{C}$ for 2 minutes. The reaction was completed with an extension step at $72^{\circ} \mathrm{C}$ for 5 minutes. All samples were removed from the thermal cycler and stored at $-20^{\circ} \mathrm{C}$. The PCR product was determined by electrophoresis with loading $8 \mu \mathrm{L}$ of PCR product on to $1 \%$ agarose gel. The gel was stained with ethidium bromide and photographed using gel-documentation system (Hoefer PS 500XT) [29]. The PCR products of $16 \mathrm{~S}$ rRNA gene of each sample were purified by the PCR purification kit (Vivantis, GF-PC-100, Malaysia) following the manufacturer's instructions. The 16S rRNA gene products of eight bacteria isolates were sequenced. The clean PCR product was subjected to cycle sequencings in both directions using the universal primers. The sequencing was done by ABAPRISM Dye Terminator Cycle Sequencing method (NHK Bioscience Solutions Sdn. Bhd). The nucleotide sequences were edited using the software Chromas and compared with published sequences in the National Center for Biotechnology Information, Genbank, using the BLAST software. Phylogenetical analyses of 16S rRNA gene sequences were aligned using the software CLUSTAL W 1.8. The phylogenetical analysis was conducted using the Neighbor Joining Method. Then, the output trees were performed with the software Molecular Evolutionary Genetics Analysis version 4.0 (MEGA 4) [29].

\section{Results and Discussion}

3.1. 16S rRNA Gene Analysis. Two universal oligonucleotides were used to determine and identify the $16 \mathrm{~S}$ rRNA gene for all isolates. The primer amplified the gene successfully from all of the phosphate solubilizing bacterial isolates, although there were no obvious variations in the size of rRNA gene products between the eight bacterial isolates. The size of the 16S rRNA gene product of all isolated bacteria in this study was about $1.4 \mathrm{~Kb}$ to the relative DNA size marker (Figure 1 ). The $16 \mathrm{~S}$ rRNA gene sequence of phosphates solubilizing bacteria that was isolated from oil palm soil was compared with Genbank and received the accession numbers (Table 2). The $16 \mathrm{~S}$ rRNA gene sequences allowed separation between isolates at the species level.

It is also important to consider that, for the identification of isolates from oil palm soil, it is not necessary to sequence the whole $1,500 \mathrm{bp}$ length and thus partial sequencing can provide necessary information, even though the whole sequencing that includes the entire $1,500 \mathrm{bp}$ region might be useful to distinguish between particular strains.

Comparison of the partial 16S rDNA sequence of eight isolates with Genbank database showed that they belong to two taxonomic lineages. Five isolates belonged to the Beta subdivision of Proteobacteria, one isolate was Gama subdivision of Proteobacteria, and two isolates were Firmicutes. Bacterial isolates of $6 \mathrm{upmr}, 2 \mathrm{upmr}, 19 \mathrm{upmnr}, 10 \mathrm{upmr}$, and 24upmr were identified as Alcaligenes faecalis. Also, bacterial 
TABLE 2: Identification and relationship of PSB isolates based on 16S rDNA marker data.

\begin{tabular}{|c|c|c|c|c|c|c|c|c|}
\hline Name & Kingdom & Phylum & Class & Order & Family & Genus & Species & $\begin{array}{c}\text { Accession } \\
\text { number } \\
\text { (NCBI) }\end{array}$ \\
\hline 17upmnr & Bacteria & Firmicutes & Bacilli & Lactobacillales & Enterococcaceae & Vagococcus & V. carniphilus & KJ783452 \\
\hline 20upmnr & Bacteria & Firmicutes & Bacilli & Bacillales & Bacillaceae & Bacillus & B. cereus & KJ729602 \\
\hline 19upmnr & Bacteria & Proteobacteria & Betaproteobacteria & Burkholderiales & Alcaligenaceae & Alcaligenes & A. faecalis & KJ748593 \\
\hline 6upmr & Bacteria & Proteobacteria & Betaproteobacteria & Burkholderiales & Alcaligenaceae & Alcaligenes & A. faecalis & KJ729608 \\
\hline $2 \mathrm{upmr}$ & Bacteria & Proteobacteria & Betaproteobacteria & Burkholderiales & Alcaligenaceae & Alcaligenes & A. faecalis & KJ748586 \\
\hline 10upmr & Bacteria & Proteobacteria & Betaproteobacteria & Burkholderiales & Alcaligenaceae & Alcaligenes & A. faecalis & KJ748585 \\
\hline $24 u p m r$ & Bacteria & Proteobacteria & Betaproteobacteria & Burkholderiales & Alcaligenaceae & Alcaligenes & A. faecalis & KJ748587 \\
\hline 31upmr & Bacteria & Proteobacteria & Gammaproteobacteria & Enterobacteriales & Enterobacteriaceae & Serratia & S. plymuthica & KJ729609 \\
\hline
\end{tabular}

isolates of 20upmnr and 17upmnr were identified as Bacillus cereus and Vagococcus carniphilus, respectively, and bacterial isolates of 3lupmr was identified as Serratia plymuthica (Table 2). Before, it had been reported that Pseudomonas, Bacillus, and Rhizobium strains are the most powerful and abundant strains of bacterial phosphate solubilizers [31]. Also, the genera of Aspergillus, Penicillium, Klebsiella, Burkholderia, and Staphylococcus are better phosphate solubilizers in Colombia oil palm plantation [13]. However, Bacillus, Rhodococcus, Arthrobacter, Serratia, Chryseobacterium, Delftia, Gordonia, and Phyllobacterium genus were better in Taiwan [32]. Furthermore, the phylogenetic diversity of phosphate solubilizing bacteria (PSB) distributed in soil of China was characterized and members of Proteobacteria were dominant. Most of the isolates were associated with the genera of Burkholderia, Pseudomonas, Acinetobacter, Enterobacter, Pantoea, Serratia, Klebsiella, Leclercia, Raoultella, and Cedecea [33]. Also, researcher reported that most phosphate solubilizing bacteria (PSB) in a crop/pasture rotation in Uruguay were related to the genera of Burkholderia, Acinetobacter, and genus Pseudomonas [34].

The 16S rRNA gene analysis revealed that all of isolates belong to the genera Alcaligenes, Serratia, Bacillus, and Vagococcus. The most often observed species of the beta Proteobacter genus was Alcaligenes. Sequences from eight isolates were completely or higher than $98 \%$ similar to other 16S rRNA sequences from database. The isolates 19upmnr, 6upmr, 2upmr, 24upmr, and 31upmr had 99\% and 17upmnr isolate had $98 \%$ similarity with other isolates in gene bank database (NCBI) (Table 2).

The phylogenetic analysis based on the partial 16S rRNA gene sequencing could classify the three main taxonomic lineages (Figure 2). The sequences obtained from Alcaligenes, Serratia, Bacillus, and Vagococcus genera formed separated branches from one another. There are three phylogeny branches that belong to Alcaligenes strains (6upmr, 10upmr, 2upmr, 19upmnr, and 24upmr), Serratia (31upmr), bacillus (20upmnr), and Vagococcus (17upmnr) (Figure 2). All isolates form three distinct clusters based on near fulllength 16S rRNA gene sequence analysis. Cluster $\mathrm{C} 1$ belongs to Alcaligenes strains that were isolated from rhizosphere and nonrhizosphere environment at Serdang (UPM) soil. Comparison of sequences revealed a greater genetic diversity

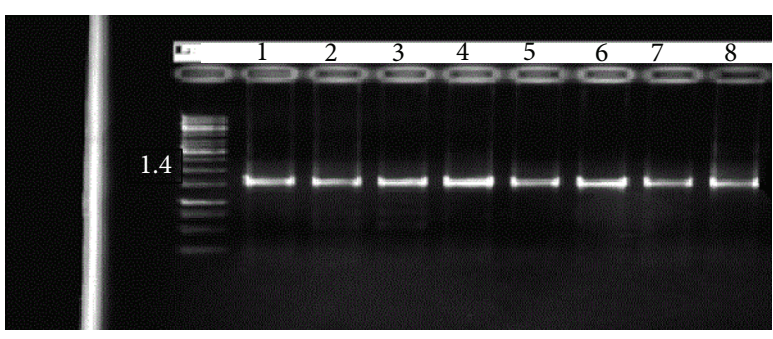

FIGURE 1: PCR products of $16 \mathrm{~S}$ rDNA (Line $1=20$ upmnr, Line $2=$ 19upmnr, Line $3=6 \mathrm{upmr}$, Line $4=10 \mathrm{upmr}$, Line $5=31 \mathrm{upmr}$, Line 6 = 2upmr, Line $7=24$ upmr, and Line $8=17$ upmnr).

in Alcaligenes strains. Isolate 31upmr from UPM rhizosphere formed separate cluster (C2), while the other showed close relationship with each other (cluster C3). These results suggested that the Alcaligenes genus grouped at cluster $\mathrm{C} 1$ was diverse and needed another molecular marker to distinguish between them.

It suggested that a physiological stress or effects of environment led to selection of less diverse communities in bacterial populations and general suppression of high solubilizing activity. The results showed the differences in the isolate's sequences in two areas of sampling, while most isolated bacteria from nonrhizosphere and rhizosphere belonged to Alcaligenes species. Rhizosphere bacteria were more diverse because of the population compared with nonrhizosphere.

\section{Conclusion}

In conclusion, conservation region in the $16 \mathrm{~S}$ rRNA gene sequence could identify all isolates of phosphate solubilizing bacteria isolated from oil palm soil successfully. This sequence can serve as a good molecular chronometer for identification of phosphate solubilizing bacteria with no previous knowledge. The degree of gene conservation is considered to be a significant part of cell identification. This study, also, shows that partial sequencing can provide statistically valid measurements for evolutionary distances of phosphate solubilizing isolates. Assigning a numerical value to the rate of change in phosphate solubilizing isolates can make taxonomic groups for all isolates. Furthermore, it shows 


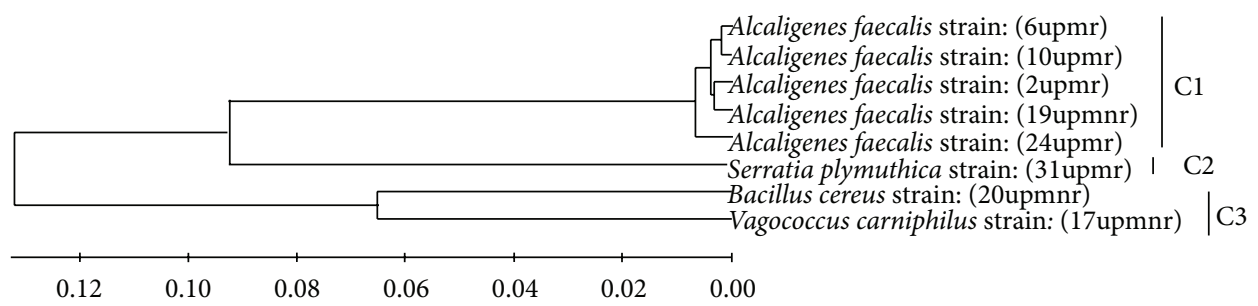

FIGURE 2: The dendrograms of cluster analysis showing the identification and relationship of UPM's PSB isolates based on 16S rRNA gene.

that the rate of change in phosphate solubilizing isolates can be different at University Putra field. Finally, no gene has shown as broad applicability over all the taxonomic groups as the 16S rRNA gene. Thus, if the objective would be to identify an unknown isolates, the $16 \mathrm{~S}$ rRNA gene sequence is an excellent and extensively used choice.

\section{Conflict of Interests}

The authors declare that there is no conflict of interests regarding the publication of this paper.

\section{References}

[1] K. G. Raghothama, "Phosphate acquisition," Annual Review of Plant Biology, vol. 50, pp. 665-693, 1999.

[2] H. Yadav, R. K. Gothwal, V. K. Nigam, S. Sinha-Roy, and P. Ghosh, "Optimization of culture conditions for phosphate solubilization by a thermo-tolerant phosphate-solubilizing bacterium Brevibacillus sp. BISR-HY65 isolated from phosphate mines," Biocatalysis and Agricultural Biotechnology, vol. 2, no. 3, pp. 217-225, 2013.

[3] A. Jungk, B. Seeling, and J. Gerke, "Mobilization of different phosphate fractions in the rhizosphere," Plant and Soil, vol. 155156, no. 1, pp. 91-94, 1993.

[4] F. Ali Shah, Q. Mahmood, M. M. Shah, A. Pervez, and S. A. Asad, "Microbial ecology of anaerobic digesters: the key players of anaerobiosis," The Scientific World Journal, vol. 2014, Article ID 183752, 21 pages, 2014.

[5] P. Lidder and A. Sonnino, "Chapter 1-biotechnologies for the management of genetic resources for food and agriculture," in Advances in Genetics, T. F. Stephen, F. Goodwin, and C. D. Jay, Eds., pp. 1-167, Academic Press, 2012.

[6] V. V. Shenoy and G. M. Kalagudi, "Enhancing plant phosphorus use efficiency for sustainable cropping," Biotechnology Advances, vol. 23, no. 7-8, pp. 501-513, 2005.

[7] J. F. B. Querido, J. Agirre, G. A. Marti, D. M. A. Guérin, and M. S. Silva, "Molecular techniques for dicistrovirus detection without RNA extraction or purification," BioMed Research International, vol. 2013, Article ID 218593, 3 pages, 2013.

[8] R. G. Burns, J. L. DeForest, J. Marxsen et al., "Soil enzymes in a changing environment: current knowledge and future directions," Soil Biology \& Biochemistry, vol. 58, pp. 216-234, 2013.

[9] S. G. Dastager, W.-J. Li, I. Saadoun, and M. Miransari, "Microbial diversity-sustaining earth and industry," Applied and Environmental Soil Science, vol. 2011, Article ID 459195, 2 pages, 2011.

[10] R. Farina, A. Beneduzi, A. Ambrosini et al., "Diversity of plant growth-promoting rhizobacteria communities associated with the stages of canola growth," Applied Soil Ecology, vol. 55, pp. 44-52, 2012.

[11] A. Krimitzas, I. Pyrri, V. N. Kouvelis, E. Kapsanaki-Gotsi, and M. A. Typas, "A phylogenetic analysis of greek isolates of Aspergillus species based on morphology and nuclear and mitochondrial gene sequences," BioMed Research International, vol. 2013, Article ID 260395, 18 pages, 2013.

[12] K.-Y. Kim, M.-H. Ko, H. Liu et al., "Phylogenetic relationships of Pseudorasbora, Pseudopungtungia, and Pungtungia (Teleostei; Cypriniformes; Gobioninae) inferred from multiple nuclear gene sequences," BioMed Research International, vol. 2013, Article ID 347242, 6 pages, 2013.

[13] E. Acevedo, T. Galindo-Castañeda, F. Prada, M. Navia, and H. M. Romero, "Phosphate-solubilizing microorganisms associated with the rhizosphere of oil palm (Elaeis guineensis Jacq.) in Colombia," Applied Soil Ecology, vol. 80, pp. 26-33, 2014.

[14] S. A. Ahmad, M. Y. Shukor, N. A. Shamaan, W. P. M. Cormack, and M. A. Syed, "Molybdate reduction to molybdenum blue by an antarctic bacterium," BioMed Research International, vol. 2013, Article ID 871941, 10 pages, 2013.

[15] T. Jagielski, J. Van Ingen, N. Rastogi, J. Dziadek, P. K. Mazur, and J. Bielecki, "Current methods in the molecular typing of Mycobacterium tuberculosis and other Mycobacteria," BioMed Research International, vol. 2014, Article ID 645802, 21 pages, 2014.

[16] A. Felske, A. Wolterink, R. van Lis, and A. D. L. Akkermans, "Phylogeny of the main bacterial 16S rRNA sequences in drentse A grassland soils (The Netherlands)," Applied and Environmental Microbiology, vol. 64, no. 3, pp. 871-879, 1998.

[17] M. A. Kertesz, E. Fellows, and A. Schmalenberger, "Rhizobacteria and plant sulfur supply," in Advances in Applied Microbiology, S. S. Allen, I. Laskin, and M. G. Geoffrey, Eds., pp. 235-268, Academic Press, 2007.

[18] A. Beneduzi, D. Peres, P. B. da Costa, M. H. Bodanese Zanettini, and L. M. P. Passaglia, "Genetic and phenotypic diversity of plant-growth-promoting bacilli isolated from wheat fields in southern Brazil," Research in Microbiology, vol. 159, no. 4, pp. 244-250, 2008.

[19] J. Ghyselinck, S. L. S. Velivelli, K. Heylen et al., "Bioprospecting in potato fields in the Central Andean Highlands: screening of rhizobacteria for plant growth-promoting properties," Systematic and Applied Microbiology, vol. 36, no. 2, pp. 116-127, 2013.

[20] G. Tsiamis, D. Karpouzas, A. Cherif, and K. Mavrommatis, "Microbial diversity for biotechnology," BioMed Research International, vol. 2014, Article ID 845972, 3 pages, 2014.

[21] C. Spampinato and D. Leonardi, "Molecular fingerprints to identify Candida species," BioMed Research International, vol. 2013, Article ID 923742, 10 pages, 2013. 
[22] J. M. Bremner, "Determination of nitrogen in soil by the Kjeldahl method," Journal of Agricultural Sciences, vol. 55, pp. 11-13, 1960.

[23] R. H. Bray and L. T. Kurtz, "Determination of total, organic and available forms of phosphorus in soils," Soil Science, vol. 59, no. 1, pp. 339-445, 1945.

[24] A. C. Chang, A. L. Page, and B.-J. Koo, "Biogeochemistry of phosphorus, iron, and trace elements in soils as influenced by soil-plant-microbial interactions," in Developments in Soil Science, P. M. H. J. M. B. A. Violante and L. Gianfreda, Eds., pp. 43-57, Elsevier, 2002.

[25] W. L. Lindsay and W. A. Norvell, "Development of a DTPA soil test for zinc, iron, manganese, and copper," Soil Science Society of America Journal, vol. 42, no. 3, pp. 421-428, 1978.

[26] C. A. Oliveira, V. M. C. Alves, I. E. Marriel et al., "Phosphate solubilizing microorganisms isolated from rhizosphere of maize cultivated in an oxisol of the Brazilian Cerrado Biome," Soil Biology and Biochemistry, vol. 41, no. 9, pp. 1782-1787, 2009.

[27] C. S. Nautiyal, "An efficient microbiological growth medium for screening phosphate solubilizing microorganisms," FEMS Microbiology Letters, vol. 170, no. 1, pp. 265-270, 1999.

[28] M. B. Javadinobandegani, Distribution and Biochemical and Genotypic Comparison of Phosphate Solubilizing Bacteria in Oil Palm Soils, Department of Agriculture Technology, Universiti Putra Malaysia, Selangor, Malaysia, 2008.

[29] J. Sambrook, Molecular Cloning: A Laboratory Manual, Cold Spring Harbor Laboratory Press, Cold Spring Harbor, NY, USA, 2001.

[30] W. G. Weisburg, S. M. Barns, D. A. Pelletier, and D. J. Lane, "16S ribosomal DNA amplification for phylogenetic study," Journal of Bacteriology, vol. 173, no. 2, pp. 697-703, 1991.

[31] B. C. Behera, S. K. Singdevsachan, R. R. Mishra, S. K. Dutta, and H. N. Thatoi, "Diversity, mechanism and biotechnology of phosphate solubilising microorganism in mangrove-a review," Biocatalysis and Agricultural Biotechnology, vol. 3, no. 2, pp. 97110, 2014.

[32] Y. P. Chen, P. D. Rekha, A. B. Arun, F. T. Shen, W.-A. Lai, and C. C. Young, "Phosphate solubilizing bacteria from subtropical soil and their tricalcium phosphate solubilizing abilities," Applied Soil Ecology, vol. 34, no. 1, pp. 33-41, 2006.

[33] P.-X. Yang, L. Ma, M.-H. Chen et al., "Phosphate solubilizing ability and phylogenetic diversity of bacteria from p-rich soils around dianchi lake drainage area of China," Pedosphere, vol. 22, no. 5, pp. 707-716, 2012.

[34] G. Azziz, N. Bajsa, T. Haghjou et al., "Abundance, diversity and prospecting of culturable phosphate solubilizing bacteria on soils under crop-pasture rotations in a no-tillage regime in Uruguay," Applied Soil Ecology, vol. 61, pp. 320-326, 2012. 

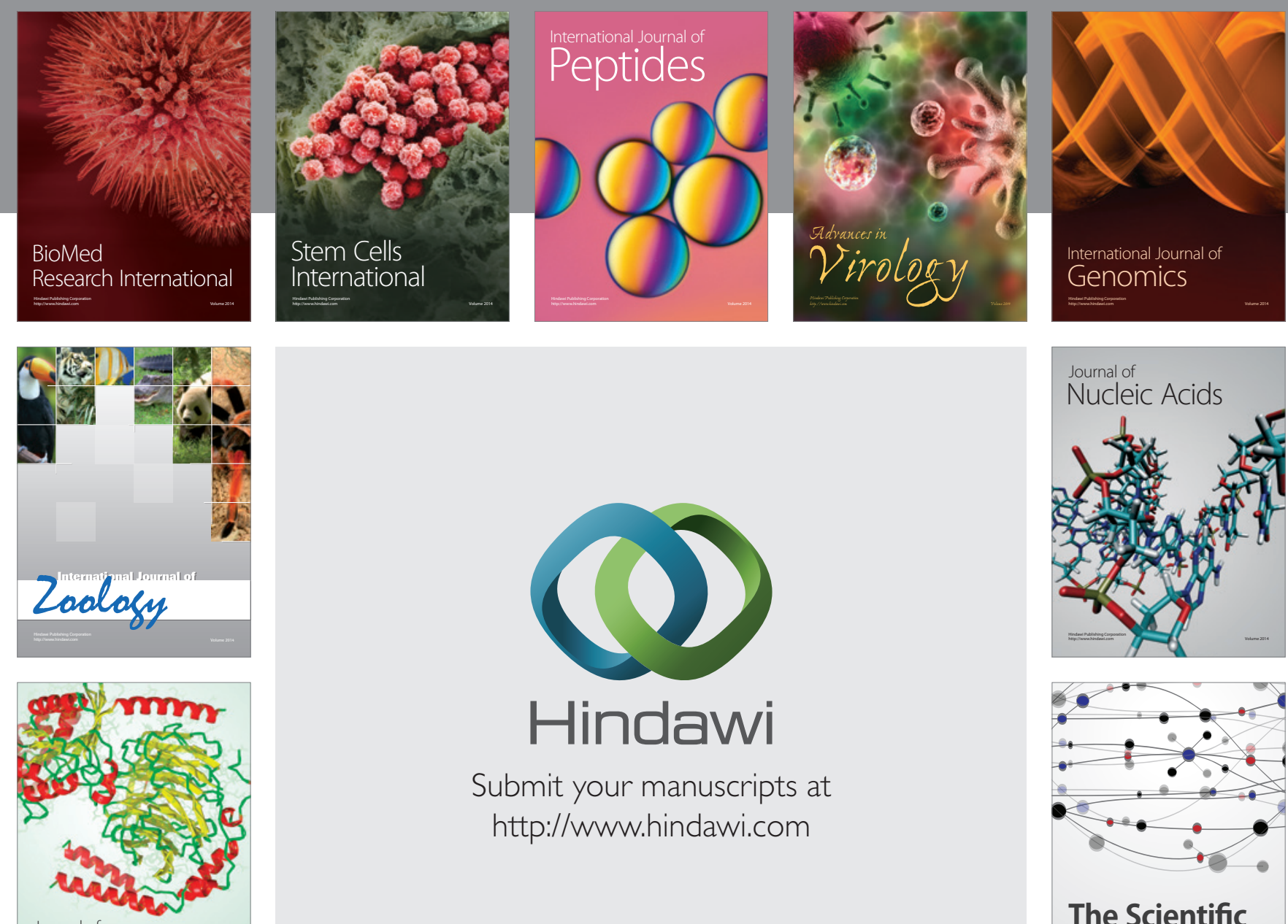

Submit your manuscripts at

http://www.hindawi.com

Journal of
Signal Transduction
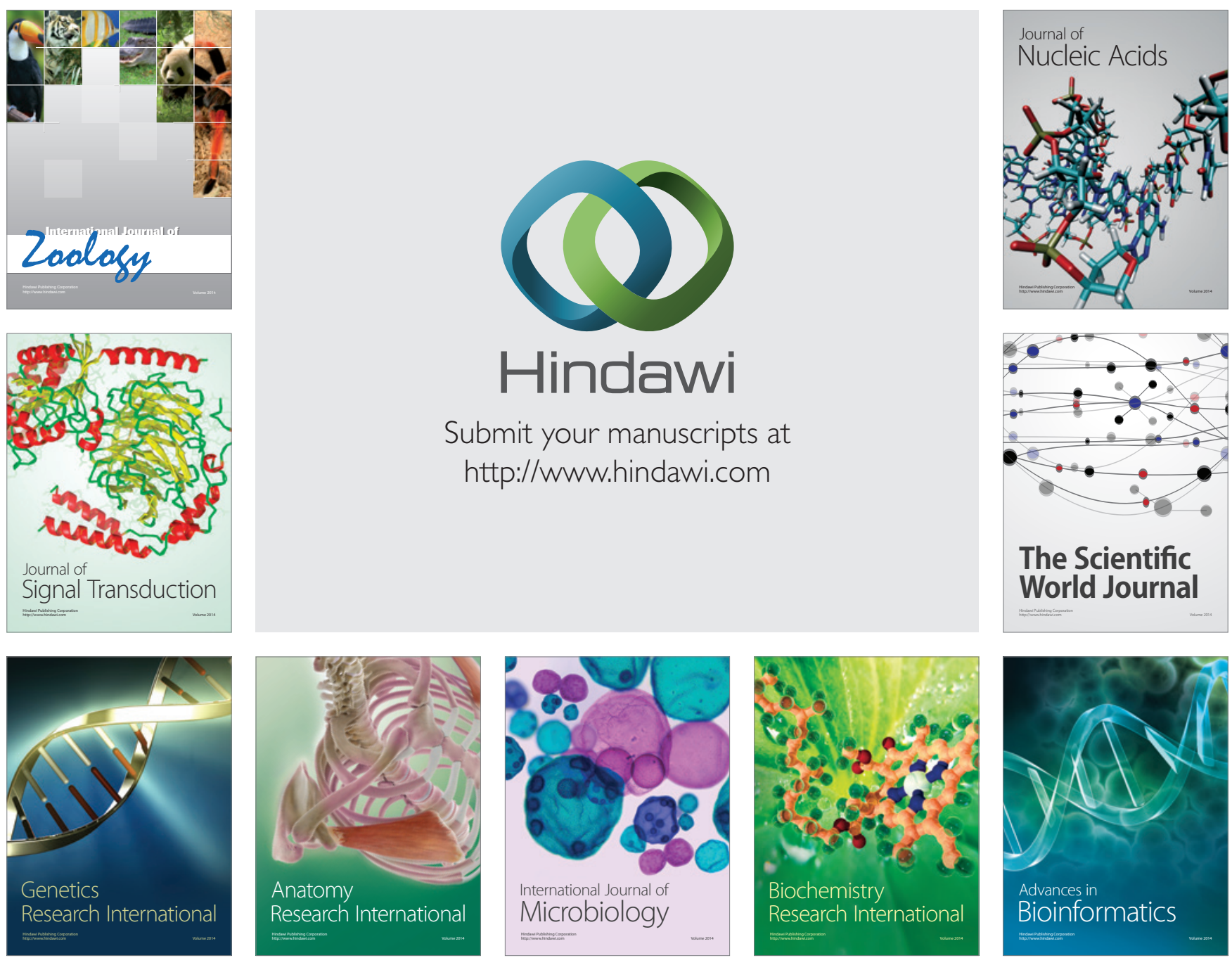

The Scientific World Journal
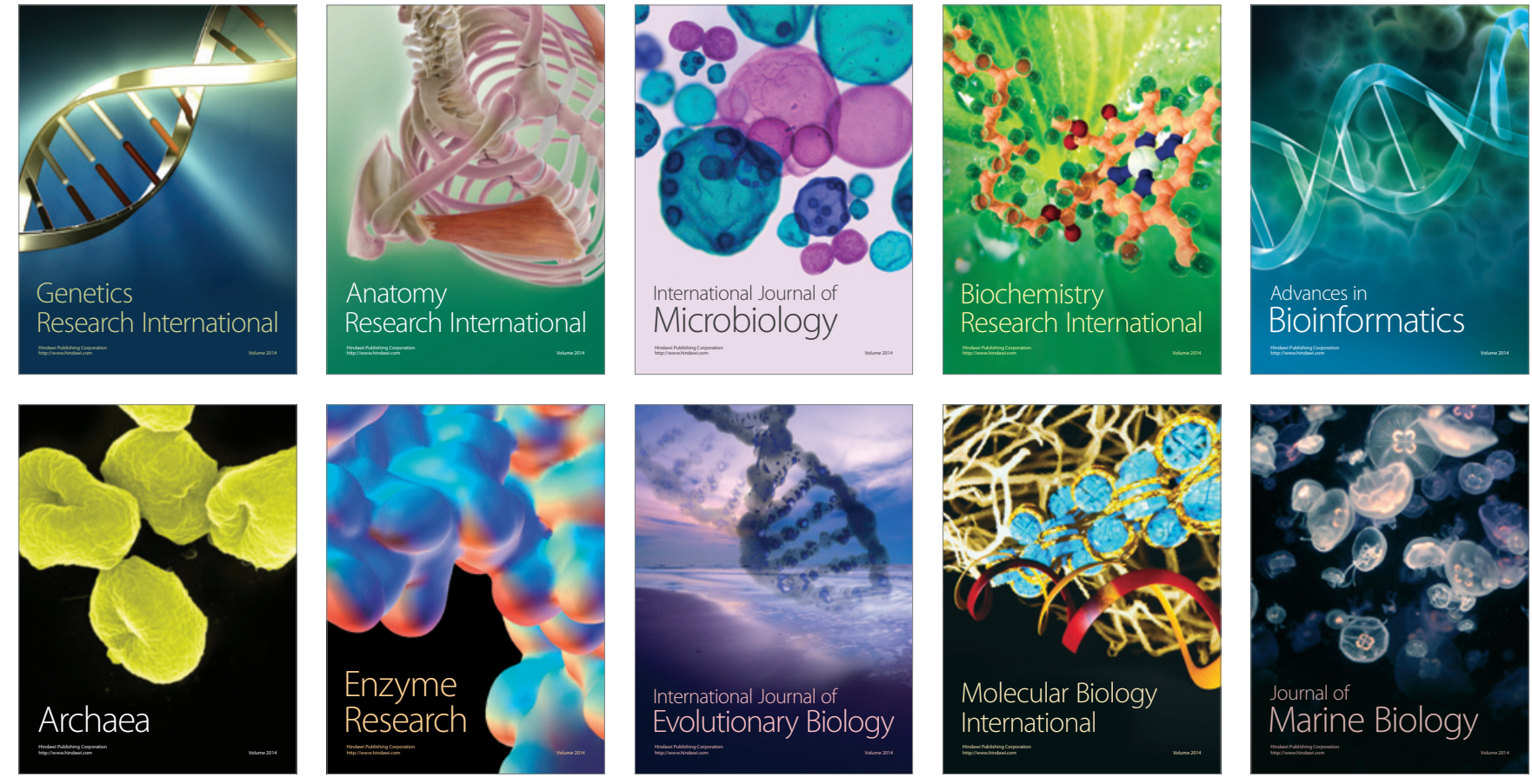